\title{
Relationship between Emotional Eating and Big Five Personality Characteristics and Mood Disorder Symptoms ${ }^{1}$
}

\author{
Ece TINMAZOĞLU2 \& Neslim GÜVENDER-DOKSAT³
}

\begin{abstract}
Some recent research indicates that eating behavior is related to emotions rather than physical hunger. The aim of this study was to investigate the relationship between emotionally triggered eating behavior and mood disorder symptoms and personality characteristics. The sample of the research consisted of 300 university students between 17-25 years old. The measurements are a socio-demographic, Emotional Appetite Questionnaire, Mood Disorder Questionnaire, and The Big Five Inventory. Data were analyzed performing T-Tests, correlation and regression analysis. Results indicated that there is a significant relationship between mood disorder symptoms, some of the emotional eating appetite sub-dimensions and some variables of Big Five personality traits of agreeableness, neuroticism, conscientiousness, and extroversion personality. There was no relationship between mood disorders and emotional eating behaviors. Extroversion, openness, and conscientiousness were significant predictors of positive mood appetite, anxiety-based mood appetite, and dysphonic mood appetite.
\end{abstract}

Key Words: Emotions, eating, personality, appetite, Big Five, traits

Emosyonel Yeme, Beş Büyük Kişilik Özellikleri ve Duygu Durum Bozuklukları Belirtileri Arasındaki İlişkiler

$\ddot{O} z$

Alan yazındaki son araştırmalardan bazıları yeme davranışın fiziki bir açlıktan çok duygularla ilişkili olduğunu vurgulamaktadır. Bu çalışmanın amacı, duygusal olarak tetiklenen yeme davranışı ile duygudurum bozukluğu belirtileri ve kişilik özellikleri arasındaki ilişkiyi incelemektir. Araştırmanın örneklemini 17-25 yaş arası 300 üniversite öğrencisi oluşturmuştur. Ölçme araçları sosyo-demografik formu, Duygusal İştah Anketi, Duygudurum Bozukluğu Anketi ve Büyük Beşli Kişilik Envanteridir. Veriler T-Testleri, korelasyon ve regresyon analizi ile analiz edilmiştir. Sonuçlar, duygudurum bozukluğu belirtileri, bazı duygusal yeme iştah alt boyutları ile bazı Büyük Beşli kişilik özelliklerinin uyumluluk, nevrotiklik, vicdanlllık ve dışa dönük kişilik özelliklerinin değişkenleri arasında anlamlı bir ilişki olduğunu göstermiştir. Duygudurum bozuklukları ile duygusal yeme davranışları arasında ilişki bulgulanmamıştır. Dışa dönüklük, açıklık ve vicdanlılık, sırasıyla olumlu duygudurum iştahı, kaygıya dayalı duygudurum iştahı ve disforik duygudurum iştahının önemli bir belirleyicisidir.

Anabtar Kelimeler: Duygular, Yemek, Kişilik, Iştah, Büyük Beşli, Karakter

\section{Atıf İçin / Please Cite As:}

Tinmazoğlu, E., \& Güvender-Doksat, N. (2020). Relationship between emotional eating and big five personality characteristics and mood disorder symptoms. Manas Sosyal Araștirmalar Dergisi, 9(1), 34-46.

Geliş Tarihi / Received Date: 07.02.2019

Kabul Tarihi / Accepted Date: 24.06.2019

\footnotetext{
1 This study was conducted by Ece Tinmazoğlu's master of thesis's titled 'The Relationship between Eating Behaviour with Emotions and Mood Disorder Symptoms and Personality Characteristics in Male and Female.' Institute of Social Sciences Department of Clinical Psychology, Beykent University. We thank Dr. Murat Artiran for his contribution in preparation of this article.

2 PhD Student - Istanbul Arel University, ece_tinmazoglu@hotmail.com - ORCID: 0000-0002-8096-5990

${ }^{3}$ Doctor - Beykent University, neslimdoksat@doksat.com - ORCID: 0000-0002-5896-0165
} 


\section{Introduction}

The issue of emotional eating is mostly addressed with regard to obesity, eating disorders and diet. However, emotional eating may also be associated with other psychopathologies and individuals with certain personality traits may exhibit this eating behavior. The emotional eating mechanisms are not wellinvestigated and well-understood moreover between stresses and eating are far less studied (Debeuf, Verbeken, Van Beveren, Nathalie, \& Caroline, 2018). Eating is one of the basic biological needs of people and, apart from biological necessity, eating has a psychological importance as well. It has been observed that eating behavior is related with emotions rather than hunger (McCrone, Dennis, Tomoyasu, \& Carroll, 2000, p. 1010). Emotional eating (EE) (appetite) is a kind of eating behavior that occurs without any feeling of hunger, rather as a response triggered by positive or negative emotions (Bekker, Meerendonk \& Mollerus, 2004, p. 466). This phenomenon may relate with low sense of self, emotions of inadequacy and eating disorders. Emotional eating behavior has been found to be a response to loneliness, anxiety and depression among overweight people (Blair, Lewis \& Booth, 1990: 154). Blair, et al. stated that emotional stimuli among people cause psychological problems during their diet because of "strong emotional stress and pressure". People might eat more when they feel angry towards someone or feel under pressure, or they might eat less when they are excited or stressed (Özgen, Kınac1, \& Arl1, 2012, p. 244). Studies about the effect of emotions on eating behaviors are mostly related with obesity, diabetes and eating disorders; however changes in eating behaviors observed in personal disorder studies remain inadequately examined (de Kloet, Pati, Wang, Hiller, Sumners, Frazier, \& Krause, 2013, p. 4831; Lux, \& Kendler, 2010, p. 1682).

Although EE initially referred to bulimia nervosa effect explaining the excessive eating of bulimic patients, it has also been observed in other eating behaviors during binge eating episodes. Therefore, awareness and importance of emotional eating is increasing, especially in guiding healthy eating behavior (Chesler, 2012). Studies have indicated that eating behavior can be a (powerful) positive or negative emotional stimulant (Ganley, 1989).

Certain studies show that eating behavior patterns and food choices are established in the first two years of age and may develop into obesity and eating disorders in cases of abnormal behavior. Children's eating behavior is highly influenced by the eating behavior of their parents. It has also been observed that children who received food prizes during their upbringing associated food with a virtual feeling of pleasure and were (therefore) more susceptible to emotional eating. Again, it has been stated in several studies that children's eating habits are pioneered by parents' habits. (Ozer et al, 2014).

$\mathrm{EE}$ is a learned strategy which aims to cope especially with emotions, and is presumably/often/likely a response to uncontrollable emotions (Kaplan, \& Kaplan, 1957, p. 189). It is often related with obesity, eating disorders and diet. Additionally, it might be related with other psychopathologies and people with specific characteristics. However, there is a lack of evidence in Turkish literature to determine if specific personality characteristics and moods are related with eating behavior.

The aim of this study is to explain the relationship between eating behavior triggered by emotions and mood disorder symptoms, and personality characteristics among female and male university students in Turkey. Eating behavior triggered with emotions is referred to as "emotional eating" in some studies on eating disorders and obesity (Lux, \& Kendler, 2010, p. 1680). Awareness and importance of EE behavior has been increasing in the formation of healthy eating behavior (Chesler, 2012, p. 182). There are also studies on positive or negative emotional stimuli in eating behaviors (Ganley, 1989, p. 8). EE behavior is generally done at home and in secret (Taylor, Parker, Bagby, \& Bourke, 1996, p. 563; Waller, \& Mataba, 1999, p. 337). It can be observed among people in normal weight as well as with bulimic people, and it is stated to be the pattern of inappropriate coping strategy (Carver, Scheier, \& Weintraub, 1989, p. 267; Spoor, Bekker, Van Strien, \& Van Heck, 2007, p. 368). Eating behavior is affected from emotions; various studies show that eating behavior is related with psychological needs and is affected by emotional states (Özgen et al., 2012: 244). For instance, food intake increases under emotions of anger, depression, anxiety, and sadness (Arnow, Kenardy, \& Agras, 1992, p. 161). While people have fast, careless and impulsive eating behavior, in the case of anger, they have hedonist eating behavior, while preferring healthy and tasty food when they are cheerful (Macht, 1999, p. 133). In a study carried out with female students, it was observed that negative emotions such as distress, anxiety and depression cause and trigger binge eating attacks (Vanderlinden, Grave, Vandereycken, \& Noorduin, 2001, p. 81). 
Being coherent is assumed to be acting in the same pattern in any case and any environment. For instance, an extravert is likely to be an extravert in any environment. Introvert personality characteristics are seen in every cognitive, motivational and emotional process that influences our behaviors and feelings (Burger, 2006, p. 504). Researchers agree that basic differences in adulthood can be explained with the "Big Five Personal Traits". These are neuroticism, extraversion, conscientiousness, openness and agreeableness. These traits were determined to be adaptable to all cultures and are assumed to be coherent and reliable. Studies also show that personal traits can be predicted even in late childhood and adolescence (Bee, \& Boyd, 200, p. 103). There are a number of studies which show that anomalous eating behavior increases with positive and negative emotions compared to neutral conditions. Eating behavior changes as a result of emotional stimuli (Canetti, Bachar, \& Berry, 2002, p. 157). Van Strien and Ouwens (2003, p. 292) stated that people who have EE behavior increase food consumption due to sadness, stress and loneliness. These people found a means of coping with negative emotions in this way (Kemp, Bui, \& Grier, 2010: 223). People with normal weight could see the difference between these two criteria while obese individuals could not understand the difference between disorganized emotions and affected emotions, nor discriminate between emotions (Van Strien, Frijters, Bergers, \& Defares, 1986, p. 301). Annagür, Orhan, Özer, Tamam, \& Erhan (2011, p. 15) stated that the most common psychological traits among people who have obesity are impulsivity, perfectionism, low self-efficacy and dissatisfaction from body perception. Obese individuals are more impulsive than weak ones, and impulsive people cannot control eating behaviours, gravitating towards high-calorie food (Annagür et al., 2011, p. 15). Arnow, Kenardy and Agras (1995, p. 81) found a significant relationship between emotional eating and binge eating behaviour.

There are several prominent theories concerning eating behavior. For instance, according to obesity theory of Kaplan and Kaplan (1957, p. 191), obese people eat excessively in order to cope with their anxiety when they are anxious and stressful. Similarly, consuming high amounts of food enables dopaminergic activation and forms a compulsive behavior mechanism that has a relaxing effect (Annagür, 2010, p. 576). Since they lack the internal control that determines how much and when they should eat, their eating behavior becomes excessive in case of stress and anxiety (Bruch, 1941, p. 161). According to internal-external obesity theory of Schachter, while anxiety and fear decrease eating behavior among people with normal weight, this is not the case among obese people since they are indifferent towards internal stimuli (Schachter, 1968, p. 1968). People eat according to their feelings, rather than the feeling of hunger and fullness (Ouwens, van Strien, \& Van der Staak, 2003, p. 292). According to escape theory, overeating behavior is done in order to escape from the stressor, which is a threat to the ego. People escape from truth by focusing their attention somewhere else, in this case by overeating (Wallis, \& Hetherington, 2004, p. 41). Macht (2008, p. 4) proposed the "five-way model" related with the way emotions affect eating behavior. In this model, study groups are composed of those whose eating behavior is restrained (diet making trend) and those who exhibit emotional eating behavior. In the perspective of learning, negative feelings challenge stimuli through eating behavior and thereby negative feelings decrease. This may occur by negative support of negative emotions (Macht, 2008, p. 5). Digestion of food with high fat and carbohydrate content decreases the effects of stress by decreasing activity in hypothalamic-pituitary- adrenaline axis (Macht 2008, p. 5). The problem of the study is to investigate the symptoms of personality and mood disorder and emotional behavior triggered by male and female university students. Sub problems of the research include to investigate whether (1) relationship between emotional eating (emotional appetite) sub-dimensions and personality traits exist, (2) the personality feature sub-dimension have a significant effect on emotional eating behavior, (3) there a significant difference between emotional eating behavior and those with and without symptoms of mood disorders.

\section{Method}

\section{Study Model}

This study was carried out according to casual-comparative and correlation study models. Casualcomparative models seek to determine the cause and effect between dependent and independent variables. The differences between emotional eating behaviors, symptoms of mood disorders, differences of gender variable and personality characteristics in emotional eating behavior were analyzed through T-test and ANOVA analyses. In a correlation study, variables are not manipulated, but only determined (Büyüköztürk, Çakmak, Akgün, Karadeniz, \& Demirel, 2008, p. 15). A correlation (relational) study tries to find the degree of relation between two or more variables (Büyüköztürk et al., 2008, p. 15). The relation between emotional eating (emotional appetite) behavior and personal traits was investigated. The effect of 
personal traits on emotional eating behavior was analyzed for statistically significant relations. T-test analysis were additionally included to find whether there is a difference in emotional eating behavior in the sense of gender variable and difference between those who have or do not display mood disorder symptoms in the sub-dimensions of emotional eating behavior. Moreover, average values of these variables were obtained.

\section{Sample}

The sample of study consisted of 320 female and male students between 17-25 years old, with a mean age of 20.83 (SD=1.685). Participants were selected randomly with convenient sampling method. The students were chosen on a volunteer basis in spring semester of 2016-2017 academic year. Data of 20 students with psychiatric disorders were excluded from the study in order not to be confounding factor and data was analyzed with 300 students. Participants were given an informed consent form and were informed about the confidentiality about their identification. It was assumed that participants understand and read the questions in the survey form carefully and answered them sincerely.

\section{Measurements}

Emotional Appetite Questionnaire (EMAQ) (Nolan, Halperin, \& Geliebter, 2010, p. 318) was used in order to measure eating behavior triggered with emotions of participants. The Questionnaire evaluated the effects of both positive and negative emotions on changing body mass index cases. Demirel, Yavuz and Kraeer's Turkish validity and reliability of emotional appetite questionnaire was included (2014, p. 176). Cronbach's Alpha reliability values of the Turkish version of the scale was calculated as .73; for subscales of this study .88 for "Positive mood appetite" factor; .81 for "Anxiety based mood appetite" factor and .70 for "Dysphoric mood appetite" factor. The scale has 22 items with 9 point Likert type scale. The scale was evaluated as in 9 point Likert type as being less (1-4), same (5) and more (6-9). Existence of emotional eating is determined with negative/positive emotion in the first 14 items and evaluation of negative/positive cases in the last 8 items. In this study, Cronbach's Alpha value of the scale was calculated as .82.

Hirschfeld, Williams and Spitzer (2000, p. 1874) developed Mood Disorder Questionnaire (MDQ) originally screening symptoms of bipolar disorders. It is a questionnaire with yes and no questions of the The Diagnostic and Statistical Manual of Mental Disorders-IV (DSM-IV) (American Psychiatric Association, 1994). The Turkish adaptation and validity study of mood disorder scale was performed by Konuk, Kıran, Tamam, Karaahmet, Aydın and Attk (2007, p. 152). There are 3 sub-scales on this selfreport measurement. The first sub-scale composed of 13 sub-items measuring manic and hypomanic symptoms. In this study, the MDQ screening had adequate internal consistency (0.79).

The Big Five Inventory (BFI) was developed by Benet-Martinez and John in 1998. It has 44 items. The scale was prepared to determine five personal traits: extroversion, neuroticism, conscientiousness, agreeableness and openness to experience, which were measured with 8, 8, 9, 9, and 10 items respectively. It is 5 -point Likert type scale $(1=$ Totally Disagree to $5=$ Totally agree). The Turkish adaptation of the scale was made by Sümer and Sümer (2005); its validity and reliability were proved in an intercultural sense. Neuroticism, extroversion, "openness, "agreeableness" and "conscientiousness" dimensions internal consistency coefficient values were $.79, .77, .76, .70$ and .78 respectively. In this study Cronbach alpha reliability value of factors of the scale is .78 for extroversion, .74 for neuroticism, .78 for conscientiousness, .71 for agreeableness and .76 for openness.

\section{Process}

First, scores taken from emotional appetite scale were analyzed based on gender, age, body mass index (BMI), family status, weight satisfaction, effort of losing weight and mood variables. Skewness and kurtosis values were calculated to determine whether data is normally distributed for each group to be compared (Field, 2009, p. 103; Gravetter, \& Wallnau, 2014, p. 113-114; Trochim, \& Donnelly, 2006, p. 57). Results showed that there was no Kurtosis or Skewness values apart from \pm 2 interval. Emotional appetite scores were normally distributed. After this stage, it was decided to make analyses by using parametric tests. Data were analyzed using SPSS 22.0. Analysis results were taken in 95\% confidence level and $p<0,05$ values were accepted to be statistically significant. Pearson Correlation Technique Analysis and Multiple Regression Analysis with stepwise method were used to find the relations between scores of emotional appetite sub-scales and five personal traits inventory variables. Necessary assumptions were 
checked before regression analysis. For this aim, scatter plot matrix confirmed multivariate normality and linearity between data. It was observed that multivariate normality and linearity is met on a great scale. Data was also analysed to determine any multicollinearity problem between data. Correlation coefficient, which determines relation between variables, was calculated and analysed. Higher correlation values $(\mathrm{r} \geq 0,9)$ indicate a multicollinearity problem (Çokluk, Şekercioğlu, \& Büyüköztürk, 2012, p. 12). Outcomes indicate no high-level relationship between the data and therefore no multicollinearity problem for regression analysis.

\section{Results}

Frequency of all variables in socio-demographic scale used in the study. Categorical classification of those with and without mood disorder, their rates and sub-groups are shown in descriptive information table (Table 1).

Table 1. Descriptive Information of Participants

\begin{tabular}{|c|c|c|c|}
\hline Group & Sub Group & Frequency (n) & Percentage (\%) \\
\hline \multirow{2}{*}{ Gender } & Female & 182 & 60,7 \\
\hline & Male & 118 & 39,3 \\
\hline \multirow{3}{*}{ Marital Status } & Single & 297 & 99,0 \\
\hline & Married & 2 &, 7 \\
\hline & Divorced & 1 & ,3 \\
\hline \multirow{4}{*}{ Weight Satisfaction } & Quite satisfied & 42 & 14,0 \\
\hline & Satisfied & 141 & 47,0 \\
\hline & Dissatisfied & 100 & 33,3 \\
\hline & Quite dissatisfied & 17 & 5,7 \\
\hline \multirow{6}{*}{ Diet Frequency } & Always & 15 & 5,0 \\
\hline & Quite Often & 10 & 3,3 \\
\hline & Often & 26 & 8,7 \\
\hline & Sometimes & 63 & 21,0 \\
\hline & Rarely & 74 & 24,7 \\
\hline & Never & 112 & 37,3 \\
\hline \multirow{4}{*}{ Body mass index (BMI) } & Overweight and obese & 226 & 75,3 \\
\hline & Normal weight & 42 & 14,0 \\
\hline & Thin & 32 & 10,7 \\
\hline & Total & 300 & 100,0 \\
\hline
\end{tabular}

\section{Gender differences}

Emotional appetite score averages were analyzed by comparing according to gender. According to Table 2, positive mood appetite $\left(\mathrm{t}_{(290)}=0,02 ; \mathrm{p}>0,05\right)$ and dysphoric $\operatorname{mood}$ appetite $\left(\mathrm{t}_{(290)}=-0,39 ; \mathrm{p}>0,05\right)$ score averages are not significantly different according to gender. On the other hand, anxiety based mood appetite(s) of males are significantly higher than that/those of females $\left(\mathrm{t}_{(290)}=-4,30 ; \mathrm{p}>0,05\right)$. Anxiety based mood appetite of males are significantly higher than females.

Table 2. T-Test Results for Emotional Appetite Scores and Gender Groups

\begin{tabular}{|c|c|c|c|c|c|c|c|c|}
\hline \multirow{2}{*}{ Scores } & \multirow{2}{*}{ Gender } & \multirow{2}{*}{$N$} & \multirow{2}{*}{$\bar{X}$} & \multirow{2}{*}{ Ss } & \multirow{2}{*}{$S H_{X}$} & \multicolumn{3}{|c|}{$t$-Test } \\
\hline & & & & & & $T$ & $S d$ & $P$ \\
\hline \multirow{2}{*}{ Positive mood } & Female & 179 & 39,53 & 9,33 & 0,70 & 0,02 & 290,00 & 0,98 \\
\hline & Male & 113 & 39,50 & 7,95 & 0,75 & & & \\
\hline \multirow{2}{*}{ Anxiety based mood } & Female & 179 & 21,08 & 8,25 & 0,62 & $-4,30$ & 290,00 & 0,00 \\
\hline & Male & 113 & 25,32 & 8,14 & 0,77 & & & \\
\hline \multirow{2}{*}{ Dysphoric mood } & Female & 179 & 17,93 & 6,44 & 0,48 & $-0,86$ & 290,00 & 0,39 \\
\hline & Male & 113 & 18,58 & 6,01 & 0,57 & & & \\
\hline
\end{tabular}

\section{Emotional appetite scores and mood disorders}

Emotional appetite score averages were analyzed by comparing mood disorder symptoms. As seen in Table 3, positive mood appetite $\left(\mathrm{t}_{(290)}=0,97 ; \mathrm{p}>0,05\right)$, anxiety based mood appetite $\left(\mathrm{t}_{(290)}=-0,69 ; \mathrm{p}>0,05\right)$ and dysphoric mood appetite $\left(\mathrm{t}_{(290)}=0,11 ; \mathrm{p}>0,05\right)$ score averages are not significantly different according to mood disorder symptoms. 
Table 3. Comparison of Emotional Appetite According to Mood Disorder Symptoms

\begin{tabular}{|c|c|c|c|c|c|c|c|c|}
\hline \multirow{2}{*}{ Scores } & \multirow[b]{2}{*}{ Mood } & \multirow{2}{*}{$N$} & \multirow{2}{*}{$\bar{X}$} & \multirow{2}{*}{ Ss } & \multirow{2}{*}{$S H_{X}$} & \multicolumn{3}{|c|}{$t$-Test } \\
\hline & & & & & & $t$ & $S d$ & $P$ \\
\hline \multirow{2}{*}{ Positive mood } & Disorder sympt. & 62 & 40,48 & 7,80 & 0,99 & 0,97 & 290,00 & 0,33 \\
\hline & No symptoms & 230 & 39,26 & 9,06 & 0,60 & & & \\
\hline \multirow{2}{*}{$\begin{array}{l}\text { Anxiety based } \\
\text { mood }\end{array}$} & Disorder sympt. & 62 & 22,06 & 7,68 & 0,97 & $-0,69$ & 290,00 & 0,49 \\
\hline & No symptoms & 230 & 22,90 & 8,66 & 0,57 & & & \\
\hline \multirow{2}{*}{ Dysphoric mood } & Disorder sympt. & 62 & 18,26 & 5,98 & 0,76 & 0,11 & 290,00 & 0,91 \\
\hline & No symptoms & 230 & 18,16 & 6,36 & 0,42 & & & \\
\hline
\end{tabular}

\section{Correlation Analyses}

According to the aim of the study, relationships between emotional appetite and personal traits were analyzed by using Pearson correlation technique. Results are given in Table 4. Extroversion personality trait has a relationship with positive mood appetite. Neuroticism personality trait has no relationship with any of the emotional appetite moods. Conscientiousness personality trait has a relationship with anxietybased appetite and dysphoric mood appetite. Openness personality trait has relationships with anxietybased appetite and dysphoric mood appetite. Agreeableness has a relationship with positive mood appetite. All relationships were weak (between $\mathrm{r}=.12$ to .25). Mood disorder symptoms have weak relationships with extroversion, conscientiousness and openness. Mood disorders symptoms have no relationship with any of the emotional appetite moods.

Table 4. Relationships Between Emotional Appetite and Personal Traits

\begin{tabular}{|c|c|c|c|c|c|c|c|c|c|c|c|}
\hline Variables & $M$ & $S D$ & 1. & 2. & 3. & 4. & 5. & 6. & 7. & 8. & 9. \\
\hline 1. Positive mood & 39.46 & 9.441 & 1 & & & & & & & & \\
\hline 2. Anxiety based & 22.97 & 8.931 & -.03 & 1 & & & & & & & \\
\hline 3. Dysphoric mood & 18.39 & 6.502 & -.76 & $.44^{* *}$ & 1 & & & & & & \\
\hline 4. Extroversion & 27.94 & 5.506 & $.12^{*}$ & .05 & .02 & 1 & & & & & \\
\hline 5. Neuroticism & 16.01 & 2.729 & -.05 & .06 & .07 & -.03 & 1 & & & & \\
\hline 6. Conscientiousness & 16.73 & 3.664 & .07 & $-.13^{*}$ & $-.13^{*}$ & $.16^{* *}$ & $-.19^{* *}$ & 1 & & & \\
\hline 7. Openness & 7.36 & 2.174 & .06 & $.16^{* *}$ & $-.16^{* *}$ & $.25^{* *}$ & .05 & $.20^{* *}$ & 1 & & \\
\hline 8. Agreeableness & 10.69 & 1.691 & $.12^{* *}$ & -.04 & -.04 & $.19^{* *}$ & $-.12^{*}$ & $.16^{* *}$ & $.12^{*}$ & 1 & \\
\hline 9. Mood Disorder & 7.73 & 2.753 & -.02 & -.01 & -.02 & $.28^{* *}$ & $.12^{*}$ & $-.11^{*}$ & .07 & .04 & 1 \\
\hline
\end{tabular}
$N=300,{ }^{*} p<0,01,{ }^{*} p<0,05$

\section{Regression analyses}

Multiple Regression analyses with stepwise method were applied in order to find whether neuroticism, extroversion, agreeableness, openness, and conscientiousness personal traits have significant effects on sub-dimensions of emotional eating behavior (Positive mood appetite; Anxiety based mood appetite and Dysphoric mood appetite). Results are given in Tables 5, 6 and 7. According to the results, extroversion has a significant effect on positive mood appetite, openness has an effect on anxiety-based mood appetite, and conscientiousness an effect on dysphoric mood appetite. Neuroticism and agreeableness have no significant relation with any of the emotional appetite sub-dimensions.

\section{Extroversion personal traits and positive mood appetite}

The effect of extroversion personal trait scores on positive mood scores were analyzed using stepwise multiple regression analysis. Results given in Table 5 show that extroversion has a significant effect $(\mathrm{p}=.03)$ on positive mood appetite $(\mathrm{R}=.124)$, with $1.5 \%$ changes in response variable $\left(\mathrm{R}^{2}=0.015\right)$. Other personal traits do not have any effect on positive mood scores. In the standardized coefficients (33.501288) for extroversion $(\beta=.124, p=.03)$ is significant.

Table 5. Stepwise Multiple Regression Analysis Outcomes: Effect of Extroversion on Positive Mood Appetite

\begin{tabular}{cccccc}
\hline Model & $\boldsymbol{R}^{2}$ & $\begin{array}{c}\text { Adjusted } \boldsymbol{R} \\
\text { Square }\end{array}$ & $\boldsymbol{F}$ & Standard error of the estimate & $\boldsymbol{P}$ \\
\hline 1 Constant & .015 & .012 & 4.687 & 9.384021 & 0,03 \\
\hline $\mathrm{p}<0,05$
\end{tabular}




\section{Openness personal traits and anxiety-based mood appetites}

The effect of openness personal trait scores on anxiety-based mood scores were analyzed using stepwise multiple regression analysis. Results given in Table 6 show that openness has a significant $(p=.047)$ effect on anxiety-based mood appetite $(R=.163)$. There are $2.6 \%$ changes in response variable $\left(\mathrm{R}^{2}=0.026\right)$. Other personal traits have no effect on anxiety-based mood scores. In the results of standardized coefficients (27.893) for extroversion $(\beta=.163, p=.047)$ is significant.

Table 6. Stepwise Multiple Regression Analysis Outcomes: Effect of Openness on Anxiety-Based Mood Appetite

\begin{tabular}{lccccc}
\hline Model & $\boldsymbol{R}^{2}$ & $\begin{array}{c}\text { Adjusted } \boldsymbol{R} \\
\text { Square }\end{array}$ & $\boldsymbol{F}$ & Standard error of the estimate & $\boldsymbol{P}$ \\
\hline 1 Constant & .026 & .023 & 8.091 & 8.82707 & 0,047 \\
\hline $\mathrm{p}<0,05$ & & & & &
\end{tabular}

\section{Conscientiousness personal traits and dysphoric mood appetite}

The effect of conscientiousness personal trait scores on dysphoric mood appetite scores were analyzed using stepwise multiple regression analysis. Results given in Table 6 show that conscientiousness has a significant $(p=.02)$ effect on dysphoric mood appetite $(R=.163)$. There are $1.4 \%$ changes in response variable $\left(\mathrm{R}^{2}=0.014\right)$. Other personal traits have no effect on dysphoric mood appetite. In the standardized coefficients (22.347) for conscientiousness $(\beta=-.133, p=.02)$ is significant.

Table 7. Stepwise Multiple Regression Analysis Outcomes: Effect of Conscientiousness on Dysphoric Mood Appetite

\begin{tabular}{lccccc}
\hline Model & $\boldsymbol{R}^{2}$ & $\begin{array}{c}\text { Adjusted } \boldsymbol{R} \\
\text { Square }\end{array}$ & $\boldsymbol{F}$ & Standard error of the estimate & $p$ \\
\hline 1 Constant & .018 & .014 & 5.378 & 6.45518 & 0,02 \\
\hline $\mathrm{p}<0,05$ & & & &
\end{tabular}

Results indicate a significant relationship between mood disorder symptoms, some emotional eating appetites sub-dimensions and the agreeableness, neuroticism, conscientiousness, and extroversion personalities variables of the Big Five personality traits. There was no relationship between mood disorders and emotional eating appetites. Extroversion, openness, and conscientiousness were significant predictors of positive mood appetite, anxiety-based mood appetite, and dysphoric mood appetite respectively.

\section{Discussion}

This study was conducted to investigate personal characteristics, emotional eating behaviors, and mood disorder symptom relationships. The findings indicate that there is a relationship between personal traits and emotional eating, even that specific personal traits are the precursors of emotional eating. According to the results, extroversion, openness, and conscientiousness were significant predictors of positive mood appetite, anxiety-based mood appetite, and dysphoric mood appetite, respectively. This finding is consistent/similar with previous studies.

Eating behavior and emotional arrangement in negative cases can be explicable through emotional regulation (Nolan et al., 2010, p. 318). In order to suppress their feelings, individuals arrange their emotional status by consuming copious amounts of their favorite foods (Evers, Marjin, \& Ridder, 2010, p. 802). It can be said that people who have neurotic personality traits arrange their emotions in a negative situation through eating. Appetite in anxiety-based mood has low level of negative-oriented and significant relationship with conscientiousness personality traits. As conscientiousness personality trait scores decrease, appetite in anxiety-based mood increases. According to five factor personal traits theory, selfdisciplined people are organized, cautious, responsible people who are in search of success. Therefore, they have reached their aims and obtain their vital needs. As conscientiousness score decreases, people are more likely to be exposed to tough conditions in the sense of status and position and are unable to attain their targets. Their resources and supports are limited and it is natural that their appetite would decrease in anxiety-based mood. It can be said that people with low conscientiousness, like people who have neurotic personal traits, can arrange their eating emotions in negative conditions. According to research by Heaven and colleagues, neuroticism and conscientiousness personality traits were significantly related to restrained, emotional and external eating behaviors. Emotional eaters tend to be emotionally unstable, thus it can be said that they lack conscientiousness (Heaven, Mulligan, Merrilees, Woods, \& Fairooz, 2001, p. 163). Therefore, low conscientiousness is a pre-disposition to emotional eating according to Heaven, et al. 
(2001, p. 163).

Fassino, Amianto, Gramaglia, Fachini and Daga (2004, p. 88) stated that, in the sense of personality traits; anorexic people are shy and submissive while bulimic people are histrionic, undulate mood and are vivid in a social sense. Eating disorder symptoms have a low level relationship with neuroticism and openness and also have relationship with conscientiousness and agreeableness (Cassin, \& Ranson, 2005, p. 903). In this study, neuroticism, conscientiousness and agreeableness personal traits have significant relationships with appetite in anxiety-based mood. When the findings of this study are compared with the findings of Cassin and Ranson, eating disorder and emotional eating are considered in the sense of personal traits, since neuroticism, conscientiousness and agreeableness personal traits are related both with eating disorder and emotional eating. Podar, Hannus and Allik (1999, p. 145) also indicated in her research that neuroticism, conscientiousness and openness are precursors of eating disorders. Increase of negative emotions and decrease of positive emotions also have significant relationships with eating disorders, with sadness having the greatest effect. In our study, sadness is the negative emotion experienced during appetite in dysphoric mood and it has been found that conscientiousness personality trait has an effect on dysphoric mood appetite (Podar et al., 1999, p. 145).

Shugar and Krueger (1995, p. 24) reported that people with eating disorders have low tolerance, anger and aggression. Moreover, it was also observed that introvert and aggressive personality, defined as a subject unable to defend their rights and expressing high anger, are related with eating disorders (Fassino, Daga, Piero, Leombruni, \& Rovera, 2001, p. 761). In a subsequent study, it was observed that obese patients who have binge eating disorder are more aggressive and angrier compared to normal weight control group and obese patient group without binge eating disorder (Fassino, Leombruni, Piero, Daga, \& Rovera, 2003, p. 559). Fassino et al. analyzed temper and character of obese females with and without binge eating disorder, and reported that obese females who have binge eating disorder are highly nervous and passive. Alexithymia was found to be the precursor of emotional eating among people who have binge eating disorder (Zeeck, Stelzer, Linster, Joos, \& Hartmann, 2011, p. 435). Other studies found that obese individuals were) alexithymic than those of normal weight (Pinna, Lai, Pirarba, Orrù, Velluzzi, Loviselli and Carpiniello (2011, p. 168). Alexithymia has a positive relationship with neuroticism, depression, anxiety, psychoticism, introversion, and has an adverse relationship with extroversion (Espina, 2003, p. 553). In 1988, Bruch stated that difficulties in distinguishing and defining emotions (identifying reactions received through emotional statements from internal organs) forms the basis of eating disorders. In the studies of Shugar and Krueger (1995, p. 29), Fassino et al. (2001, p. 761) and Fassino et al. (2003, p. 559), it was stated that people who were diagnosed with an eating disorder were commonly nervous and aggressive. When the studies of Shugar et al. (1995, p. 29), Fassino et al. (2001, p. 761) are compared with this study, since nervosity is a sub-definition of neuroticism according to five factor personality traits, it is coherent that neuroticism is related with emotional eating and eating disorders. While Bruch (1998: 32) stated that difficulties in making distinction and defining emotions is precursor of eating disorders and Zeeck et al. (2011, p. 435) that alexithymia is the precursor of eating disorders, Espina stated in 2003 that alexithymia has a positive oriented and significant relationship with neuroticism and a negative oriented significant relationship with extroversion. According to the common deduction in the studies of Zeeck et al. (2011, p. 436), Brunch Bruch (1998: 36) and (Espina, 2003, p. 553); since alexithymia, which is a precursor of eating disorder, has a positive oriented relationship with neuroticism and a negative oriented relationship with extroversion, it has consistency with neurotic personal trait which has positive oriented and significant relationship with anxiety based in other words negative emotional eating. Since, in this study, extrovert personality trait predicts positive emotional eating, it has adverse consistency with the finding of extrovert behavior, which has a negative oriented relationship with alexithymia (Espina, 2003, p. 552).

In the regression analyses it was understood that extroversion scores are a significant precursor of appetite in positive mood while harmonious personal trait scores have a significant relationship with appetite in anxiety-based mood. This finding is quite important since, through induction, it can be projected that harmonious people have anxiety-based emotional appetite. Similarly, it can be said that extroverted people have an appetite for positive mood. No other study was found specifically on this subject.

Elfhag and Morey (2008, p. 291) found in their research that emotional eating in obese people is strongly positively significant to neuroticism, in particular impulsiveness, sensitivity and depression, with a 
lower significance to conscientiousness, which is seen in lower self-discipline, and lower extraversion. This means that the inadequate self-control seen in impulsiveness and lower self-discipline was most important for eating due to negative emotions, and personality traits can help us gain insights into eating behavior (Elfhag, \& Morey, 2008, p. 290). Sutin, Ferrucci, Zonderman and Terracciano (2011, p. 581) also conducted a study on the relation of body mass index and personality traits and found that individuals higher in Neuroticism or Extraversion, or lower in Conscientiousness, had higher BMI (Sutin et. al., 2011, p. 580). In our study, extraversion scores are a significant precursor of appetite in positive mood and conscientiousness personal traits of dysphoric mood appetite, which is in line with Elfag and Morey's study. EE behaviors are by-products of emotional activation and mostly emerge together with emotions during eating (Macht, 2008, p. 9). It is also known that stress is one of the factors which affect eating behavior (Levine, 1997, p. 560; Blundell, Goodson, \& Halford, 2001, p. 32). The increase in obesity in recent years is remarkable, and one of the reasons for its rise is stress (Torres, \& Nowson, 2007, p. 891). It is observed that emotional eating is the precursor of obesity, together with bulimia nervosa and binge eating disorder together (Demirel et al., 2014, p. 176).

This study has some limitations. The sample size consisted of only a non-clinical population, and in future studies, outcomes should be tested with a clinical sample. Findings are limited to indicators of Emotional Appetite Survey, Five Factor Personal Traits Scale and Mood Disorders Scale. Yet emotional eating can be related with other psychological variables and psychopathologies. People with specific personal traits might have dysfunctional eating behavior. More research is needed to draw firm conclusion on how eating behavior occurs and the relationship between eating behavior that can increase or decrease with emotionality, conditioning and reinforcement. Culturally sensitive studies are also needed to understand emotions and eating relationships. For instance, in the treatment of psychotherapy there is a need for culture-based therapeutic methods (Artiran, 2019, p. 4); this also applies to emotional eating problems because emotions differ culture to culture. In future, association of control of emotions and eating behavior and personality traits may need to be studied in experimental studies.

\section{References}

Allport, G. W. (1961). Pattern and growth in personality. New York: Holt, Rinehart and Winston.

Amerikan Psikiyatri Birliği. (2014). DSM 5 Tanı Ölçütleri Bassvuru El Kitabı. Ankara: Hekimler Yayın Birliği.

Annagür, B. (2010). Obezitede çeşitli risk faktörleri ve dürtüsellik. Psikiyatride Güncel Yaklaşımlar, 2(4), 572-582.

Annagür, B. B., Orhan, F. Ö., Özer, A., Tamam, L. \& Erhan, Ç. (2011). Obezitede dürtüsellik ve emosyonel faktörler: bir ön çalışma. Nöropsikeiyatri Arşivi Dergisi, 49, 14-19.

Arnow, G., Kenardy, J., \& Agras, W. S. (1992). Binge eating among the obese: a descriptive study. Journal of Behavioural Medicine, 15, 155-170.

Arnow, B., Kenardy, J., \& Agras, W. S. (1995). The emotional eating scale: The development of a measure to assess coping with negative affect by eating. International Journal of Eating Disorders, 18(1), 79-90.

Artiran, M. (2019). A Cross-Cultural Redefinition of Rational Emotive and Cognitive Behavior Therapy: From the West to the Middle East. Routledge. New York, USA. doi.org/10.4324/9780429276873

Atkinson, R. C.., Atkinson, R., Daryl, J. B., Smith, E. E. \& Hoeksama, S. N. (2002). Psikolojizye Giriş. (2. baskı). İstanbul: Arkadaş Yayınları.

Bazana, P.G. \& Stelmack, R. M. (2004). Stability of personality across the life span: a meta-analysis. On the psychology of personality. Elsevier Ltd.

Bee, H., \& Boyd, D. (2009). Cocuk gelişimi psikolojisi (1. basım). İstanbul: Kaknüs Yayınları.

Bekker, M. H., Meerendonk, V., \& Mollerus, C. (2004). Effects of negative mood induction and impulsivity on selfperceived emotional eating. International Journal of Eating Disorders, 36, 461-469.

Blair, A. J., Lewis, L. J., \& Boot, D.A. (1990). Does emotional eating interfere with success in attempts at weight control. Appetite, 15, 151-157.

Blundell, J.E., Goodson, S., \& Halford, J. C. G (2001). Regulation of appetite: role of leptin in signalling systems for drive and satiety. International Journal of Obesity, 25, 29-S34.

Bruch, H. (1941). Obesity in childhood and personality development. Obesity Research, 5, 157-161.

Bruch, H. (1988). Conversations with anorexics. New York: Basic Books.

Burger, J. M. (2006). Kişilik, Psikoloji Biliminin İnsan Doğası İçin Söyledikleri. Çev. İnan Deniz Erguvan Sarıŏlu) Kaknüs Yayınlar1, İstanbul, 2006, ss. 503-505

Büyüköztürk, Ş., Çakmak, E. K., Akgün, Ö. E., Karadeniz, Ş., \& Demirel, F. (2008). Bilimsel Araştırma Yöntemleri. (11. Bask1). Ankara: Pegem Akademi.

Canetti, L., Bachar, E. \& Berry, E. M. (2002). Food and emotion. Behavioural Processes, 60, 157-164.

Carver, C. S., \& Scheier, M. F. (1996). Perpectives on personality (third edition). Boston: Allyn and Bacon.

Carver, C. S., Scheier, M. F., \& Weintraub, J. K. (1989). Assessing coping strategies: a theoretically based approach. Journal of Personal and Social Psychology, 56, 267-83. 
Cassin, S. E., \& Ranson, K. M. (2005). Personality and eating disorders: A decade in review. Clinical Psychology Review, 25, 895-916.

Chesler, B. E. (2012). Emotional eating: a virtually untreated risk factor for outcome following bariatric surgery. Scientific World Journal, 10.11000, 365961.

Costa, P. T., \& McCrae, R. (1995). Domains and facets: hierarchical personality assessment using the revised neo personality inventory, Journal of Personality Assessment, 64(1), 21-50.

Çelebi, N., \& Uğurlu, B. (2014). Resmi liselerde çalışan öğretmenlerin kişilik özelliklerinin demografik değişkenlere göre incelenmesi. Adiyaman Üniversitesi Sosyal Bilimler Enstitïsü Dergisi, 18, 537-569.

Çetin, F. (2008). Kişilerarası ilişkilerde kendilik alg1sı, kontrol odağ1 ve kişilik yapısının çatışma çözme yaklaşımları üzerine etkileri: uygulamalı bir araştırma, Yayımlanmamış Yüksek Lisans Tęৃi, KHO Savunma Bilimleri Enstitüsü, Ankara.

Çokluk, O., Şekercioğlu, G., \& Büyüköztürk, Ş. (2012). Sosyal Bilimler Için Çok Değişkenli Spss Ve Lisrel Uygulamaları. Ankara: Pegem Akademi Yayıncilik.

de Kloet, A. D., Pati, D., Wang, L., Hiller, H., Sumners, C., Frazier, C. J., \& Krause, E. G. (2013). Angiotensin type 1a receptors in the paraventricular nucleus of the hypothalamus protect against diet-induced obesity. Journal of Neuroscience, 33(11), 4825-4833.

Debeuf, T., Verbeken, S., Van Beveren M.L., Nathalie, M., \& Caroline, B. (2018). Stress and Eating Behavior: A Daily Diary Study in Youngsters. Frontiers in Psycholog. Vo. 9, p. 2657

Demirel, B., Yavuz, K. F., Karadere, M. E., Şafak, E. Y., \& Türkçapar, M. H. (2014). Duygusal iştah anketinin türkçe geçerlik ve güvenilirliği, beden kitle indeksi ve duygusal şemalarla ilişkisi. Bilişsel Davranış̧ı Psikoterapi ve Araștirmalar Dergisi, 3, 171-181.

Elfhag, K., \& Morey, L. C. (2008). Personality traits and eating behavior in the obese: poor self-control in emotional and external eating but personality assets in restrained eating. Eating behaviors, 9(3), 285-293.

Engler, B. (1985). Personality theories: an introduction. Houghton: Mifflin Company.

Espina, A. (2003). Alexithymia in parents of daughters with eating disorders, its relationships with psychopathological and personality variables. Journal of Psychosomatic Research, 55, 553-560.

Evers, C., Stok, M., Denise, T. \& Ridder, D. (2010). Feeding your feelings: emotion regulation strategies and emotional eating. Personality and Social Psychology Bulletin., 36, 792-804.

Fassino, S., Amianto, F., Gramaglia, C., Facchini, F., \& Daga, A. G. (2004). Temperament and character in eating disorders: ten years of studies. Eating and Weight Disorders., 9(2), 81-90.

Fassino, S., Daga, G. A., Piero, A., Leombruni, P., \& Rovera, G. G. (2001). Anger and personality in eating disorders. Journal of Psychosomatic Research, 51, 757-764.

Fassino, S., Leombruni, P., Piero, A., Daga, G. A., \& Rovera, G. G. (2003). Mood, eating attitudes, and anger in obese women with and without binge eating disorder. Journal of Psychosomatic Research, 54, 559-566.

Fassino, S., Leombruni, P., Piero, A., Daga, G. A., Amianto, F., Rovera, G., \& Rovera, G. G. (2002). Temperament and character in obese women with and without binge eating disorder. Comprehensive Psychiatry, Vol.43, 431-437.

Field, A. (2009). Discovering statistics using spss. London: SAGE.

Ganley, R.M. (1989). Emotion and eating in obesity: a review of the literature. International Journal Of Eating Disorders, 8, 8343-361.

Geary, N. (2003). A new model of binge eating. International Journal of Eating Disorders., 34, 198-199.

Gravetter, F., \& Wallnau, L. (2014). Essentials Of Statistics For The Behavioral Sciences (8th ed.). Belmont, CA: Wadsworth.

Greeno, C.G. \& Wing, R.R. (1994). Stress-induced eating. Psychological Bulletin,115, 444-464.

Gülcan, A. \& Nedimbal, P. (2014). Genç Yetişkinlerde İyimserliğin Mutluluk ve Yaşam Doyum Üzerindeki Etkisinin İncelenmesi. Asya Öğretim Dergisi, 2, 41-52.

Hagan, M.M., Chandler, P.C., Wauford, P.K., Rybak, R.J. \& Oswald, .K.D. (2003). The role of palatable food and hunger as trigger factors in an animal model of stress induced binge eating. International Journal of Eating Disorders, 34, 183-197.

Heaven, P. C., Mulligan, K., Merrilees, R., Woods, T., \& Fairooz, Y. (2001). Neuroticism and conscientiousness as predictors of emotional, external, and restrained eating behaviors. The International Journal of Eating Disorders, (2), 161.

Hirschfeld, R. M. A, Williams J.B.W \& Spitzer, R.L. (2000). Development and validation of a screening instrument for bipolar spectrum disorder: The Mood Disorder Questionnaire. American Journal of Psychiatry, 157:18731875.

İbiloğlu, A.O. \& Ali Çayköylü, A. (2011). Bipolar-I, bipolar-II ve majör depresif bozuklukta ayrışan sosyodemografik, klinik ve mizaç özellikleri. Türk Psikiyatri Dergisi, 22 (3), 159-65.

Kadıŏ̆lu, M., \& Ergun, A. (2015). Üniversite öğrencilerinin yeme tutumu, özetkililik ve etkileyen faktörler. Musbed, 5(2), 96-104.

Kaplan, H. I., \& Kaplan, H. S. (1957). The psychosomatic concept of obesity. Journal of Nervous and Mental Disease, $125,181-201$

Kemp, E., Bui, M., \& Grier, S. (2011). Eating their feelings: Examining emotional eating in at-risk groups in the United States. Journal of Consumer Policy, 34(2), 211-229.

Kesebir, S., Vahip. S., Akdeniz, F., \& Yüncü, Z. (2005). Bipolar bozuklukta mizaç ile klinik özelliklerin ilişkisi. Türk 
Psikiyatri Dergisi, 16(3), 164-169.

Kıcalı, G. D. (2015). Üniversite öğrencilerine beslenme alışkanlıkları ve yeme bağımlılığının farklı kişilik özellikleri ve psikiyatrik belirtilerle ilişkisinin incelenmesi. T.C. Selçuk Üniversitesi T⿰p Fakültesi, yaymlanmamıs tę:

Konuk, Kıran, S., Tamam, L., Karaahmet, E., Aydın, H., \& Atık, L. (2007). Duygudurum Bozuklukları Ölçeği'nin Türkçe uyarlamasının bipolar bozukluk taramasında geçerliği. Türk Psikiyatri Dergisi, 18(2),147-154.

Levine, A. S., \& Billington, C. J. (1997). Why do we eat? A neural system approach. Annual Review of Nutrution, 17, 597-619.

Liebert, M. L., \& Spiegler, M. D. (1990). Personality strategies and issues. California: Brooks/Cole Publishing Company.

Lux, V., \& Kendler, K.S. (2010). Deconstructing major depression: a validation study of the DSM-IV symptomatic criteria. Psychological Medicine, 40, 1679-90.

Macht, M. (1999). Characteristics of eating in anger fear sadness and joy. Appetite, 33, 129-39.

Macht, M. (2008). How emotions affect eating: A five-way model. Appetite, 50, 1-11.

Martinez, B., \& John, O. (1998). Los cinco grandes across cultures and ethnic groups: multi-trait multimethod analyses of the big five in Spanish and English. Journal of Personality and Social Psychology,75, 729-750

McCrone, S., Dennis, K., Tomoyasu, N., \& Carroll, J. (2000). A profile of early versus late onset of obesity in postmenopausal women. Journal of Women's Health \& Gender-Based Medicine, 9, 1007-1013.

Mischel, W. (1993). Introduction to personality (Fifth Edition). Florida: Harcourt Brace Jovanovich College Publishers.

Mount, M.K., Barrick, M. R., Scullen, S.M. \& Rounds, J. (2005). Higher order dimensions of the big five personality traits and the big six vocational interest types. Personal Psychology, 58, 447-478.

Nolen-Hoeksema, S. (2004). Abnormal Psychology. New York: The McGraw-Hill Companies.

Nolan, L. J., Halperin, L. B. \& Geliebter, A. (2010). Emotional appetite questionnaire. Construct validity and relationship with BMI. Appetite, 54, 314-9.

Oliver, G., \& Wardle, J. (1999). Perceived effects of stress on food choice. Physiology \& behavior, 66, 511-5.

Ouwens, M. A., van Strien, T., \& van der Staak, C. P. F. (2003). Tendency toward overeating and restraint as predictors of food consumption. Appetite, 40, 291-8.

Özer, S., Bozkurt, H., Sönmezgöz, E., Bilge, S., Yılmaz, R., \& Demir, O. (2014). Obezite Tanılı Çocuklarda Yeme Davranışının Değerlendirilmesi. Cocuk Dergisi, 14(2), 66-71.

Özgen, L., Kınac1, B., \& Arlı, M. (2012). Ergenlerin yeme tutum ve davranışları. Ankara Üniversitesi Eğitim Fakültesi Dergisi, 45(1), 229-247.

Özpoyraz, N. (?). Duygudurum bozuklukları. Çukurova Üniversitesi T1p Fakültesi, Psikiyatri Anabilim Dah Ders Notlar 8.

Patel, K. A., \& Schlundt, D. G. (2001). Impact of moods and social context on eating behavior. Appetite, 36, 111-8.

Pinna, F., Lai, L., Pirarba, S., Orrù, W., Velluzzi, F., Loviselli, A., \& Carpiniello, B. (2011). Obesity, alexithymia and psychopathology: A casecontrol study. Eating and Weight Disorders, 16, 164-170.

Podar, I., Hannus, A., \& Allik, J. (1999). Personality and affectivity characteristics associated with eating disorders: a comparison of eating disordered, weight-preoccupied, and normal samples. Journal of Personality Assessment. 73(1):133-47.

Popper, R., Smits, G., Meiselman, H. L., \& Hirsch, E. (1989). Eating in combat: a survey of U.S. Marines. Military Medicine, 154, 619-23.

Sayın, A., \& Aslan, S. (2005). Duygudurum bozukluklarii ile huy, karakter ve kişilik ilişkisi. Türk Psikiyatri Dergisi, 16(4), 276-283.

Schmitt, D. P., Allik, J., Mccrea, R. R., \& Benet-Martinez, V. (2007). The geographic distribution of big five personality traits: patterns and profilesof human self-description across 56 Nations, Journal of Cross-Cultural Psychology, 38(2), 173-212.

Shugar, G., \& Krueger, S. (1995). Aggressive family communication, weight gain, and improved eating attidudes during systematic family therapy for anorexia nervosa. International Journal of Eating Disorders, 17, 23-31.

Spindler, A., \& Milos, G. (2007). Links between eating disorder symptom severity and psychiatric comorbidity. Eating Behaviors, 8, 364-373.

Spoor, S. T., Bekker, M. H.,Van Strien, T. \& Van Heck, G. L. (2007). Relations between negative affect, coping and emotional eating. Appetite, 48, 368-76.

Sutin, A. R., Ferrucci, L., Zonderman, A. B., \& Terracciano, A. (2011). Personality and obesity across the adult life span. Journal of personality and social psychology, 101(3), 579.

Sümer, N., ve Sümer, H. C. (2005). Beş faktör kişilik özellikleri ölçeği (Yayınlanmamış çalışma).

Sümer, N., Lajunen, T. \& Özkan, T. (2005). Big five personality traits as thedistal predictors of road accident involvement. Traffic and transport psychology. Elsevier Ltd.

Tatlılıŏ̆lu, K. (2014). Üniversite öğrencilerinin beş faktör kişilik kuramına göre kişilik özellikleri alt boyutlarının bazı değişkenlere göre incelenmesi. Tarih Okulu Dergisi, Say1 17, 939-971.

Tavşancıl, E. (2005). Tutumlarm ölçülmesi ve spss ile veri analiz̨i. Ankara: Nobel Yayın Dağıtım.

Taylor, G. J., Parker, J. D., Bagby, R. M., \& Bourke, M. P. (1996). Relationships between alexithymia and psychological characteristics associated with eating disorders. Journal Of Psychosomatic, 41, 561-8.

Torres, S., \& Nowson, C. (2007). Relationship between stress, eating behavior and obesity. Nutrition, 23 (11), $887-$ 894.

Trochim, W. M., \& Donnelly, J. P. (2006). The research methods knowledge base (3rd ed.). Cincinnati, OH: Atomic Dog. 
Van Strien, T. \& Ouwens, M. A. (2003). Counterregulation in female obese emotional eaters: Schachter, Goldman, and Gordon's (1968) test of psychosomatic theory revisited. Eating Behaviors, 3, 329-340.

Van Strien, T., Frijters, J. E. R., Bergers, G. P. A., \& Defares, P. B. (1986). The Dutch eating behavior questionnaire (DEBQ) for assessment of restrained, emotional, and external eating behavior. International Journal of Eating Disorders, 5(2), 295-315.

Vanderlinden, J., Grave, R. D., Vandereycken, W., \& Noorduin, C. (2001). Which factors do provoke binge eating? An exploratory study in female students. Eating Behaviors, 2, 79-83.

Waller, G., \& Matoba, M. (1999). Emotional eating and eating psychopathology in nonclinical groups: a crosscultural comparison of women in Japan and the United Kingdom. Internal Journal of Eating Disorders., 26, 333-40.

Wallis, D. J., \& Hetherington, M. M. (2004). Stress and eating: the effects of ego threat and cognitive demand on food intake in restrained and emotional eaters. Appetite, 43, 39-46.

Woodside, Bulik, Thornton, Klump \& Tozzi (2004). Personality in men with eating disorders. Journal of Psychosomatic Research 57, 273-278.

Zeeck, A., Stelzer, N., Linster, H. W., Joos, A., \& Hartmann, A. (2011). Emotion and eating in binge eating disorder and obesity. European Eating Disorders Review, 19(5), 426-437.

\section{TÜRKÇE GENIŞ ÖZET}

Bu çalısmanın amacı, duygusal olarak tetiklenen yeme davranışı ile duygudurum bozukluğu belirtileri ve kişilik özellikleri arasındaki ilişkiyi incelemektir. İnsanlar için yemek yeme sadece fiziksel bir ihtiyaç olmanın yanı sıra psikolojik ve duygusal olarak da önem ve anlam taşıyan bir aktivitedir. Duygusal yeme konusunu daha çok obezite, yeme bozuklukları ve diyet ile ilgili olarak ele alınmaktadır. Hâlbuki emosyonel yemenin başka psikopatolojilerle de ilişkili olabilir ve belli kişilik özelliklerine sahip olan kişiler bu yeme davranışını gösterebilir. Olumsuz durumlarda yeme davranışı ve duygusal düzenleme duygusal düzenleme yoluyla açıklanabilir (Nolan vd., 2010, s. 318). Duygularını bastırmak için bireyler, en sevdikleri yemeği büyük miktarlarda tüketerek duygusal durumlarını düzenlerler (Evers, Marjin ve Ridder, 2010, s. 802). Duygusal yeme davranışının özellikle fazla kilolu insanlarda yalnızlık, kaygı ve depresyona yanıt olarak oluştuğu kanısına varılmıştır (Blair, Lewis ve Booth, 1990, s. 152). Depresyon ve bipolar gibi psikopatolojik rahatsızlılarda duygudurum değişikliğinden dolayı kişilik özelliklerinde ve yeme davranışında değişme gözlenmektedir ancak bu konuda bazı noktalar henüz aydınlatılmış değildir. Örneğin, emosyonların yeme davranışındaki etkisi üzerine yapılan çalışmalar çoğunlukla obezite, diyabet ve yeme bozukluklarıyla gündemimizdedir ve kişilik bozukluklarında sergilenen yeme davranışı farklılıkları ayrıntılı araştırılmış değildir (de Kloet, Pati, Wang, Hiller, Sumners, Frazier ve Krause, 2013, s. 4831). "Duygusal Yemek Yeme" davranışı olumlu veya olumsuz duygulanım sonucu tetiklenebilir. Bireyler, kızgın veya baskı altındayken, endişeli ve stresliyken kendilerini yemek yemeye verebilirler. Aynı zamanda kişilerin bu duygusal yemek yeme örüntüsü ile kişilik özellikleri arasında da kuvvetli bir bağ olduğu düşünülmektedir (Burger, 2006: 504). Bu araştırma planlanırken kişilik örüntüleri ile duygu durum rahatsızlıkları ve yeme bozuklukları arasında ilişkisellik olduğu varsayılmıştır. Kişilik, bireyin düşünce ve duygularıyla yaşama adaptasyonunu içeren, davranış örneklerini tanımlar (Mischel, 1993, s. 52). Kişilik özellikleri olarak bütün kültür ve toplumlarda görüldüğü düşünülen "Büyük Beşli Kişilik" alınmaktadır (Mount, Barrick, Scullen ve Rounds, 2005, s. 447). Bu kişilik özellikleri gelişime açıllk, dişa dönüklük, vicdanlllık, nevrotiklik ve uyumluluktur. Önceki araştırmalarda stres, baskı, depresyon gibi bir çok olumsuz duygunun bireylerde nasıl ve neden "duygusal yemek yeme" davranışı ortaya çıkardığı ile ilgili teori ve hipotezlere de yer verilmiştir.

$\mathrm{Bu}$ araştırmanın örneklemini 17-25 yaş arası 300 üniversite öğrencisi oluşturmuştur. Katılımcilar İstanbul ilinin üç farklı üniversitesinin çeşitli bölümlerinde lisans eğitimi alan, kolay örnekleme yöntemiyle rastgele seçilmiştir. Verilerin normal dağıllp dağılmadığı test edilmiş ve normal dağılım gösterdiği görülmüştür. Dolayısıyla istatiksel yöntem olarak nedensel karşılaştırma ve ilişkisel tarama modeli tercih edilmiştir. Veriler T-Testleri, korelasyon ve regresyon analizi ile test edilmiştir. Ölçme araçları sosyodemografik formu, Duygusal İştah Anketi, Duygudurum Bozukluğu Anketi ve Büyük Beşli Kişilik Envanteri'dir.

$\mathrm{Bu}$ çalışma, emosyonel yemeyle ilişkili ve yordayan kişilik özelliklerinin neler olduğunun ortaya konması, bunun hangi özellikteki emosyonel yemeyle ilişkili olduğu, emosyonel yeme davranışı olan bireylerin kişilerin duygudurum bozukluğu belirtisi gösterip göstermediğini araştırmak amacıyla yapılmıştır. Yeme davranışı emosyondan etkilenir ve insanın yeme davranışının psikolojik ihtiyaçlarla ilişkili olduğu çeşitli araştırmalarda dile getirilmiştir ve emosyonel duruma göre yeme davranışının da etkilendiği 
görülmüştür (Özgen, Kınacı ve Arlı, 2012, s. 244). Elde edilen bulgulara göre, kişisel özellikler ile duygusal beslenme arasında bir ilişki olduğunu, hatta belirli kişisel özelliklerin duygusal yemeğin öncüleri olduğunu gözlenmektedir. Büyük Beş kişilik özellikleri; dişa dönüklülük, nevrotiklik, gelişime açıklı, nörotiklik ve uyumluluk kişiliklerden oluşur. Elde edilen sonuçlara göre dışa dönüklük, gelişime açılık ve uyumluluk sırasıyla olumlu duygudurum iştahı, kaygıya dayalı duygudurum iştahı ve disforik duygudurum iştahının önemli bir göstergesidir. Bulguların geçmiş çalışmalarla benzer sonuçlar verdiği görülmüştür. Sonuçlar, duygudurum bozukluğu belirtileri, bazı duygusal yeme iştah alt boyutları ile bazı Büyük Beşli kişilik özelliklerinin uyumluluk, nevrotiklik, vicdanlılık ve dışa dönük kişilik özelliklerinin değişkenleri arasında anlamlı bir ilişki olduğunu göstermiştir. Disforik veya olumlu duygudurumlarında yeme davranışları hakkında cinsiyetler arası bir fark gözlemlenmemiştir. Erkeklerde anksiyete temelli bozukluklarda yeme davranışının kadınlara göre daha fazla arttığı bulgulanmıştır. Duygudurum bozuklukları ile duygusal yeme davranışları arasında ilişki bulgulanmamışır. Dışa dönüklük, açıklık ve uyumluluk, sırasıyla olumlu duygudurum iştahı, kaygiya dayalı duygudurum iştahı ve disforik duygudurum iştahının önemli bir belirleyicisidir. Regresyon analizlerinde dışa dönüklük puanlarının olumlu duygudurumda iştah öncüsü olduğu, uyumlu kişisel özellik puanlarının ise kaygı temelli durumdaki iştahla anlamlı bir ilişkisi olduğu anlaşılmıştır. Bu bulgu oldukça önemlidir, çünkü tümevarım yoluyla uyumlu insanların kaygı temelli duygusal iştahları olduğu, benzer şekilde dışa dönük insanların olumlu bir ruh hali için iştahları olduğu söylenebilir. Bu konuda özel olarak başka bir çalışma yapılmamışıtır.

Geçmişte yürütülen çalışmalar ile benzer sonuçlar elde edilmiştir. Kişilerin duygularını bastırmak için fazla miktarda yemek yemeleri psikolojik olarak anlaşılabilen bir durum olarak gözükmektedir. Nevrotik kişilik özelliklerini taşıyan bireylerde yemek yiyerek olumsuz duygudurumlarını dengelemeye çalş̧tıkları görülmüştür. Aksine uyumluluk kişilik özelliği ile birlikte anksiyete temelli iştah düşmektedir. Doğal olarak düşük uyumluluk kişilik özelliği olan bireylerde anksiyete temelli yemek aktivitesi artmaktadır. Aynı zamanda içe dönüklük de kişilerin dışa vuramadıkları öfke ve kızgınlık duygularının duygusal yemek yeme aktivitesine dönüşmesinde çokça etkilidir. Aksine, dışa dönük kişilerde ise bu davranış olumlu duygulanım ile bağdaşlaştırılmaktadır. Ayrıca kişilik özelliklerinden çokça etkilenen bu duygusal yemek yeme davranışının Bulimia Nervosa ve Tikınırcasına Yeme Bozukluğunun öncüsü olduğu gözlemlenmiştir. Sonuç olarak bu araştırmada bazı karakter özelliklerinin duygusal yeme davranışı üzerinde etkili olduğu görülmüş ve açık bir ilişki saptanmıştır. Bu araştırmanın bazı sınıllıkları vardır. Örneğin örneklem grubunun klinik olmayan evrenden seçilmesi ve sadece bir ilden (İstanbul) seçilmiş olması gibi, ayrıca araştırma bulguları kullanılan ölçeklerin ölçtüğü kavramlarla sınırlıdır. Gelecekteki araştırmalarda farklı ölçeklerin kullanılması ve farklı örneklem gruplarından toplanan veriler üzerinde değerlendirme yapılması buradaki bulguların tekrar test edilmesi için yararlı olacaktır. 